\title{
JACEK GUTOROW
}

\section{„Jesteśmy razem, ale każde z nas osobno”. Krystyna Miłobędzka i „wspólne powietrze”}

1.

\author{
„Znikam” \\ „Jestem”
}

2.

Tytuł książki przygotowanej przez Jarosława Borowca ${ }^{\mathrm{T}}$ jest odrobinę inny: znikam jestem. Zapisany kursywą i małymi literami, jakby miały na chwilę zniknąć. Co chciałyby powiedzieć przed zniknięciem? Może to: „jestem w znikaniu, znikam w byciu sobą"? Z tych kilku prostych zdań rozwija się cały poetycki bądź „poetycki” - wachlarz. Zasugerowany cudzysłów nie jest przypadkowy. Coś znika, coś zostaje - również w poezji. Kiedy znika ona sama, znika również część nas. Ale być może nie jest to część najistotniejsza? Może coś pozostaje - w cudzym słowie?

\section{3.}

Bo czego właściwie chcemy od poezji? Oczywiście poza kilkoma olśnieniami i czarodziejstwem słów? Czy możemy traktować ją poważnie w świecie, w którym ona sama nie odgrywa już żadnej roli, a jeśli nawet, to wyłącznie w dodatkach kulturalnych o wątpliwej wartości? Czy daje nam coś trwalszego niż fascynację chwilą i nostalgię związaną z powtarzaniem rytuałów czytelniczych (wieczory autorskie, nominacje i laudacje, nieśmiertelne pytania o sens życia, przyjemności czerpane z obrazów, metafor i brzmienia słów)? Jakim „nam”?

${ }^{\text {I }}$ K. Miłobędzka, znikam jestem. cztery wieczory autorskie, red. J. Borowiec, Wrocław 2010. 
Czy można pomyśleć poezję, która wychodzi poza pojedynczego czytelnika, ale nie staje się przedmiotem - czy nawet ofiarą - sentymentów zbiorowych? Czy można pomyśleć zbiorowość, która nie obciąża wiersza jakimś wspólnym odczytaniem, lecz pozwala mu rozwijać się za każdym razem inaczej, choć jednocześnie wychodzi mu naprzeciw jako wspólnota? Jaka wspólnota?

Tego rodzaju niejasności nasuwają się często podczas kolejnych moich lektur Krystyny Miłobędzkiej. Pytania pojawiły się stosunkowo późno, ale też u samej poetki postawione zostały $\mathrm{w}$ tomach i wypowiedziach późniejszych. Można dowodzić, że wiersz otwierający Anaglify jest już do pewnego stopnia wyznaniem wspólnotowym ${ }^{2}$. Ale mimo wszystko jest to chyba tekst wyjątkowy. (Jeszcze zmienię zdanie - proszę wybaczyć). Bodaj wszystkie pozostałe prozy poetyckie mają postać ćwiczeń fenomenologicznych, prób świadomości mierzącej się z bogactwem i nadmiarem świata. Miłobędzka zaczynała od oczarowania tak silnego, że nie pozostawiało ono miejsca na żadne gesty czy sytuacje wspólnotowe. Jeśli byli jacyś inni, to wyłącznie jako „niemi kontemplujący": czytelnicy tekstów, szyfrów, kodów rzeczywistości. Wyjątkowość każdej rzeczy, jej pojedynczość, fakt, że najdrobniejszy detal był przykładem, że były tylko przykłady wszystko to sprawiało, że nie do pomyślenia okazywała się liczba mnoga. Nadmiar polegał na tym, że każdy przedmiot, każda roślina, każde zwierzę, każda istota, wypełniały siebie do samego końca - tak, że nie pozostawało już miejsca na refleksję.

Ale refleksja musiała wcześniej czy później przyjść. Przybrała formę namysłu nad relacyjnym charakterem tego, co łączy rzeczy i istoty żywe. Refleksja i relacja: jak porządek dnia w późniejszych książkach Miłobędzkiej. Rozproszenie, mnogość, wielojęzyczność. A zarazem poczucie, że jeśli istnieje jakaś zasada, to nie ma ona formy archaicznej i archetypicznej. Wręcz przeciwnie, jest zasadą indywidualną, ale też wywrotową, bardziej w duchu Owidiuszowego principiis obsta niż filozoficznego principia individuationis. Czy ktoś jest w stanie wyobrazić sobie (i innym) taką wspólnotę? Ale czyż domeną poezji nie jest właśnie wyobraźnia?

\footnotetext{
${ }^{2}$ „Na szybie pokrytej parą rysujemy dwa kółka dodając uszy, wąsy i ogon. W ten sposób powstaje kot. Można także narysować świerk, kwiat albo człowieka.// Dopóki różnica temperatur po obu stronach szyby utrzymuje się ludzie, zwierzęta i rośliny istnieją w sposób nie budzący wątpliwości. Istnieją z zewnątrz i od środka?”. K. Miłobędzka, zbierane, gubione. 1960-2010, Wroclaw 2010, s. 9.
} 
Znikam. Jestem. Wiersze Miłobędzkiej to niekończące się rozstaje. Słowa wyraźnie zaznaczają swoje ścieżki, ale niosą też, równie wyraźnie, ładunek sensów niedopełnionych i nie do końca wyartykułowanych. Choć utwory poetki są zazwyczaj oszczędne, to czytelnik szybko odkrywa gęstą łunę możliwych znaczeń, które - pozostawione sobie - tworzą niejako osobne poetyckie całości, albo chociaż fragmenty całości. Wrażenie, przynajmniej moje, jest takie, jak gdyby słowa rozbiegały się na różne strony, odklejały od siebie i bezustannie przemnażały własny kapitał. Ten kapitał - w chwili obecnej dość pokaźny - nie daje się właściwie określić. Ale też poezja Miłobędzkiej jest w dużej mierze poezją przybliżeń, supozycji i domyślników. Wiele jest w niej rozwidleń, rozgałęzień i tego wszystkiego, co moglibyśmy nazwać odwodem języka, jego wieczną rezerwą, lirycznym potencjałem gestu poetyckiego.

Rzecz w tym, że rozgałęzienie można też widzieć jako zejście się, skupienie oderwanych wątków. Nie żeby heterodoksje stały się zaraz ortodoksjami. Lecz mimo że mianowniki poszczególnych wierszy nigdy nie są wspólne, to jednak „od zawsze” coś zadzierzga się na ich stykach i na linii biegnącej od poety do czytelnika (i odwrotnie). Takie sploty bardzo mnie interesują. Widzę w nich podstawową jakość charakteryzującą poezję Miłobędzkiej. Wychodzą w czytaniu, za każdym razem. I za każdym razem inaczej. Dają asumpt do mówienia o wierszach tej poetki jako miejscach wspólnych. Pozostają pytania: jakim nam? na jaki adres? w czyim imieniu?

5.

Ledwie widoczny, blednący tytuł - znikamjestem. Zapis czterech wieczorów autorskich poetki, jakie odbyły się w latach 2000-2010. Wiele interesujących uwag, w tym najważniejsza: uwaga autorki i słuchaczy. Słowa są zapisane, ale także rozbrzmiewają - jako głos, jako niczym niezwiązana obecność, tubylczość bądź nawet tu-jestestwo ${ }^{3}$. Trudny głos. Głos zakosów i rozstajów, biegnący na przełaj, ustanawiający własne racje dla tego typu okazji. Jak to możliwe, że w takiej cienkiej książeczce mieści się tyle rozbieżnych racji, tonów, częstotliwości?

3 Warto odnotować, że do książki dołączono płytę CD z zapisem jednego z legnickich spotkań. 
W listopadzie 2001 r. Miłobędzka mówiła we Wrocławiu o niewypowiedzianym wnętrzu/zewnętrzu poezji: „bywa bezwzględna, a nawet okrutna wobec języka" " . Okrutna wobec języka? Tak, bo zmienia jego naturalne szyki, wkrada się w miejsca przez chwilę nieoznaczone, jakby zarażone śmiercią bądź przynajmniej niepamięcią; bo schodzi na poziom trudnej do zaakceptowania wieloznaczności, kiedy te same słowa prowadzą w różne strony. Miłobędzka mówi nie tylko jako poetka, lecz również - a w tym konkretnym przypadku przede wszystkim - jako czytelniczka. Wrocławski wieczór zakończył się odniesieniem do pięciu ulubionych poetów: Juliusza Słowackiego, Cypriana Norwida, Bolesława Leśmiana, Mirona Białoszewskiego i Tymoteusza Karpowicza. Poetów wpisujących się w „określoną tradycję", którą można by określić jako tradycję takiego inwestowania w językowy kapitał, które sprawia, że nigdy nie jest on stały, bezpieczny i przewidywalny.

Pod koniec tamtego spotkania padły ważne słowa: „każdy z tych poetów stworzył inny język porozumiewania się ze świa-

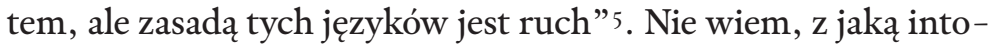
nacją zdanie to zostało wypowiedziane. Znając inne wypowiedzi poetki, można zaryzykować tezę, że akcent padł na ostatnie słowo. Chciałbym jednak podkreślić wcześniejszą frazę: „język porozumiewania się ze światem”. Sformułowanie brzmi gładko i potoczyście, ale w pisarstwie Miłobędzkiej otwiera wiele furtek i wyprowadza na często lekceważone ścieżki. Być może słowa te tchną mało zachęcającą oczywistością, ale jestem prawie pewien, że należy je odczytywać jako swego rodzaju rebus, w którym zarówno słowo „język”, jak i słowa „porozumienie”, „świat” rozgałęziają się na wszystkie strony, owijając się wokół niespodziewanych znaczeń i wydźwięków. Nie chodzi po prostu o język. I nie wprost o porozumienie. A świat, o którym tu mowa, przybiera jednocześnie tyle postaci, że staje się własnymi możliwościami i niemożliwościami, jednocześnie ustanowiony i czekający dopiero na ustanowienie.

6.

Jeden z wyborów Miłobędzkiej: Karpowicz. Wybór znamienny i pod wieloma względami zrozumiały. Bo autor Odweróconego śreiatta to także znikanie i jestestwo. Nie chcę powtarzać tez,

\footnotetext{
4 K. Miłobędzka, znikam jestem..., s. 40.

Ibidem.
} 
które wygłosiłem gdzie indziej ${ }^{6}$, dodam więc tylko, że poezję Karpowicza odczytuję również jako poezję na rozstajach i że oba dzieła są sobie na tyle bliskie, iż można je traktować jako kombinatoryczne rozwinięcie tych samych intuicji. Podobne skłonności i nawyki językowe, nieomal bliźniacze wrażliwości, zbliżone umiejętności przeskakiwania $\mathrm{z}$ jednego wersu do następnego admiratorzy książek Pani Krystyny i Pana Tymoteusza prawdopodobnie zgodzą się z twierdzeniem, że na poziomie językowym możemy mówić o porównywalnych słabościach i sentymentach. W wypowiedziach obojga poetów wyczuwalne są tony siostrzane i braterskie; wspaniałe momenty, kiedy dochodzi do spotkania dwóch wrażliwości, i które dałoby się - jak sądzę - rozpisać na formę eleganckiego kontrapunktu, składają się na coś, co trudno jednoznacznie określić, a co nazwałbym frazą wziętą z sonetu Williama Szekspira: „the marriage of true minds” („zaślubinami prawdziwych umysłów" 7).

A jednak. Karpowiczowskie „znikam jestem” wybrzmiewa odmiennym tonem, który początkowo można przeoczyć, którego jednak lekceważyć długo nie sposób. W rozmowie z Mirosławem Spychalskim i Jarosławem Szodą samotnik z Chicago mówił:

To dramatyczne, tragiczne - wszystkie moje próby osiągnięcia punktu, w którym w końcu poczuję się wolny (na ile to w ogóle możliwe?). Bo ja dotychczas nie czuję się wolny. Zbyt wiele jest jeszcze żywych elementów przeszłości. Życiorysy osób, z którymi się spotkałem, żyją obok mnie, żyje to, co w przeszłości wspólnie z tymi osobami powołałem do życia. Nie mam, najwyraźniej nie mam klucza, żeby to otworzyć, rozładować, wysypać na zewnątrz i powiedzieć sobie: przecież $\mathrm{w}$ tym nie ma nic zagrażającego. To mi się nigdy nie udało ${ }^{8}$.

Chwilę potem poeta dorzucił jeszcze: „To się wszystko tak strasznie we mnie zakorkowało. Jestem zapchany, zakorkowany sobą i naprawdę nie wiem, jak się odkorkować" 9 .

Otóż takich słów Miłobędzka nigdy by nie wypowiedziała. I to przy wszystkich podobieństwach obu poetyk, wrażliwości, tradycji. Dlaczego? Pytanie dotyczy nie tyle poezji, ile miejsca poezji. I tego, co z niej czerpiemy, co możemy czerpać, co

${ }^{6} \mathrm{~J}$. Gutorow, Urwany ślad. O wierszach Wirpszy, Karpowicza, Różewicza i Sosnowskiego, Wrocław 2007, s. 49-92.

7 Chodzi o sonet 116 - przel. J.G.

${ }^{8}$ M. Spychalski, J. Szoda, Mówi Karpowicz, Wrocław 2005, s. 71.

9 Ibidem, s. 73. 
chcemy w niej odkryć. Jest to pytanie zmierzające do utworzenia pewnej wspólnoty, choćby tylko minimalnej: wspólnoty autora i czytelnika. Sądzę, że w przypadkach obojga poetów można mówić o imperatywie wspólnotowym. Ale od razu pojawiają się różnice, i to różnice zasadnicze. Co to znaczy wspólnota? Jaki miałby być jej status, a nawet czas gramatyczny czy tryb czasowników użytych do jej opisu? Na jakich prawach taka wspólnota mogłaby bądź powinna być ufundowana? I dlaczego w miejscu skrzyżowania tych pytań rozchodzą się drogi obojga poetów? ${ }^{\text {Io }}$

Zostawiam biednego Karpowicza nad jego nieskończonymi układankami i powracam do zanotowanych przez Borowca spotkań z Miłobędzką. Od razu czuje się, że to inny klimat. Nie chciałbym ustanawiać łatwych opozycji, bo mimo wszystko wiele jest podobieństw i zbieżności. Ale po lekturze znikam jestem (tudzież po lekturze szarego śweiatła, tomu rozmów Borowca z Miłobędzką i Andrzejem Falkiewiczem) zauważa się zasadniczą różnicę.

7.

W przedmowie do książki Borowiec zaczyna od serii pytań. Każde z nich zasługuje na przywołanie i przemyślenie:

czy w publicznym spotkaniu poety z czytelnikami zdarza się coś szczególnego? Czy jednoczesne istnienie odczytywanego tekstu i autora jest czymś ważnym? Co piszący zyskuje z potwierdzenia tekstu przez osobę odbiorcy? I odwrotnie - co dla odbiorcy wynika z potwierdzenia tekstów osoba autora? Usłyszenia jego głosu? Zobaczenia go? ${ }^{\text {II }}$

ro W odróżnieniu od Miłobędzkiej Karpowicz nie myślał o czytelnikach swoich książek (a także słuchaczach obecnych na spotkaniach autorskich) w kategoriach wspólnoty: „Odbiorca jako partner nie istnieje we mnie w ogóle [...]. Nie jestem w stanie [...] podszyć się pod czyjąś percepcję, założyć, że ktoś odbierze coś tak, jak ja mu zaserwuję. To niemożliwe - żeby wynieść moje wewnętrzne lustro na zewnątrz i wstawić do czyjejś osobowości”. M. Spychalski, J. Szoda, op.cit., s. 65. Z drugiej strony, po przedstawieniu swoim rozmówcom obrazu Okopów Świętej Trójcy (świadomość-dom-ogród) jako nieprzekraczalnego dla innych terenu „siebie” Karpowicz oświadcza w pewnym momencie: „Okłamałem panów, mówiąc o Okopach Świętej Trójcy, o potrójnych wałach, za które się wycofuję: płotu, okna, zapory z ludzkiej myśli [...]. Przepraszam was. Nie wycofuję się poza te potrójne wały obronne dlatego, żeby uciec od świata rzeczywistego, ale żeby jeszcze bardziej się z nim złączyć. Być jego częścią. Bardziej niż czegokolwiek spragniony jestem konkretnego kontaktu ze światem". Ibidem, s. 75 .

II K. Miłobędzka, znikam jestem..., s. 7. 
Pytania implikują coś bardzo ważnego: najpierw wiarę w to, że poezja otwiera przestrzeń spotkania, następnie przekonanie, że każde z użytych w tym sformułowaniu słów - „spotkanie”, „przestrzeń”, „otwarcie”, „poezja”, „wiara”- jest w punkcie wyjścia sproblematyzowane, i to tak bardzo i wcześnie, że ich znaczenia są już zawsze hipotezami, które trzeba dopiero sprawdzić.

Borowiec zdaje sobie z tego sprawę, ponieważ już po chwili dodaje: „to, co wydarza się między autorem i słuchaczem, jest zawsze wielką niewiadomą" ${ }^{2}$. Właściwie każde z przywołanych wcześniej słów kluczy nie tyle otwiera, co zamyka dyskusję dlatego, że jako gest nazbyt szybko sprzeniewierza się intencji, którą chce wyrażać. A jest to intencja wsparta na przekonaniu o jednorazowości i wyjątkowości każdego spotkania autorskiego. Wspólnota autora i słuchaczy nie jest dana. Za każdym razem buduje się na nowo, jakby nigdy wcześniej nie istniała. Zarazem jest to wspólnota wychodząca poza tradycyjne znaczenie przypisywane słowu. Wychodząca niejako $\mathrm{w}$ dwóch kierunkach, bo z jednej strony spotkanie poety ze słuchaczami jest niewiadomą wynikającą $\mathrm{z}$ braku jakichkolwiek punktów wspólnych, $\mathrm{z}$ drugiej jednak strony relacje pomiędzy poetą a słuchaczami ulegają natychmiastowemu zwielokrotnieniu, które jest rezultatem przyjętej konwencji i swego rodzaju teatralizacji spotkania: słuchacze widzą poetę - ten dostrzega słuchaczy, jednak „piszący wyraźnie widzi samego siebie" I3, a publiczność - każde z nas z osobna i wszyscy razem - nabiera wymiaru scenicznego. Poeta zauważa publiczność, która w fenomenie poety dostrzega siebie - publiczność natomiast odkrywa, że poetyckie widzenie siebie jest też widzeniem i włączaniem się w pewną wspólnotę.

Zapewne są to sytuacje i gesty nie do końca uświadamiane, prawdopodobnie nawet często zupełnie nieświadome. $\mathrm{O}$ ich istnieniu zaświadczają jednak słowa samej Miłobędzkiej, dla której spotkanie autorskie rzadko jest przypadkowym wydarzeniem do odnotowania $\mathrm{w}$ kronice kulturalnej czy rocznym sprawozdaniu jednostki budżetowej. Staje się za to dynamiką poezji poza poezją, ruchem zakreślania pewnej całości, a jednocześnie wykreślania z całości tego wszystkiego, co mogłoby stanowić wyjściową własność publiczną bądź komunalną (na przykład pewne poglądy, pewna estetyka, pewne oczekiwania, pewne nostalgie) - tak, że w końcu pozostajemy z całością rozproszoną i heterogeniczną, kręgiem pozbawionym środka i obwodu, wspólnotą wytrąconą z poczucia wspólnotowości.

\footnotetext{
I2 Ibidem, s. 8.

${ }^{2} 3$ Ibidem.
} 
8.

Jak mówiła poetka 5 grudnia 2008 r. we Wrocławiu, całość jest „nieopowiadalna”: „całość zmusza do szukania połączeń. Ale całości nie da się osiągnąć. Całość jest błądzeniem, wejściem w labirynt. Całość jest nieopowiadalna, na całość nie ma słów" I4. Sformułowania te można odnieść do potencjalnej całości wytwarzanej w trakcie spotkania autorskiego. Pozostaje ona zawsze potencjalna $-\mathrm{z}$ jednej strony nie zamyka sobą ani w sobie żadnej totalności, z drugiej jednak jest stale obecna, choć obecnością utajoną. Pozostaje ruch i szukanie połączeń. Czasem Miłobędzka pisze o poezji jako zapisie „Związków piszącego ze światem” ${ }^{5}$, czasem zwraca uwagę na „związek zapisanego z tym, co zapisane”, „związek treści zapisanego z kształtem zapisanego”, a nawet „związek zapisanego z tym, na czym zostało zapisane" ${ }^{\text {} 6}$. Każde $\mathrm{z}$ tych potencjalnych połączeń jest istotne i może stanowić część całości, element wspólnoty. Dotyczy to nawet tych fragmentów, w których poetka mówi o formie i statusie zapisu, a więc momentu rzekomo sprzed spotkania i sprzed mowy. Piszę „rzekomo”, gdyż nie istnieje przecież „czysty zapis” - to, co napisane, jest już zawsze $w$ pewnym sensie mówione, posiada własną intonację, własną częstotliwość. Kształt zapisanego, medium zapisu, jego konwencja i cechy typograficzne - wszystko daje się odnieść do sytuacji spotkania autorskiego. Wystarczy wsłuchać się w głos poety ${ }^{17}$.

Całość jest nieopowiadalna, związana i przechodnia. Akcent przesuwa się z poezji na mówienie. Jeśliby rozumieć poezję jako zbiór wierszy opublikowanych $\mathrm{w}$ tomach poetyckich, to staje się

I4 Ibidem, s. 46.

15 Ibidem, s. 24.

I6 Ibidem, s. 25.

${ }^{17} \mathrm{Nie}$ musi to być głos donośny czy interesujący. Spotkanie z głosem poety jest ciekawe również wtedy, gdy okazuje się on nie najlepszym czytelnikiem i interpretatorem własnych wierszy - gdy, jak to się mówi, „czyta źle” (choć sformułowanie to nie jest tak oczywiste, jak w pierwszej chwili mogłoby się wydawać). Myślę, że nie tylko ja mam wrażenie, że interpretacja tekstu poetyckiego dokonana przez aktora dysponującego wyćwiczonym, mocnym, posłusznym głosem pozostawia w słuchaczach uczucie jakiegoś podstawowego fałszu; chociaż nie mamy wątpliwości, że aktor czyta dobrze, że prawidłowo wymawia poszczególne dźwięki i słowa, że potrafi zbudować ze słów dramatyczną całość to jednak nie możemy pominąć faktu, że głos, który słyszymy, nie jest głosem wiersza. Potknięcia, złe akcentowanie czy wymawianie dźwięków, drżenie głosu - to również pewne jakości poetyckie, często ledwie uświadamiane, ale przez to potężniejsze. Sądzę, że uwagi te dają się odnieść również do Miłobędzkiej, której sposób interpretowania własnych wierszy daleki jest od aktorskiej poprawności, która jednak właśnie dlatego przekonuje. Bo mamy do czynienia z głosem własnym. 
ona przypadkiem szczególnym, jednym z łączy między autorem a czytelnikiem. Poezja jako przestrzeń związków tworzących się między poetą i odbiorcami realizuje się w pełni w sytuacji jednorazowego, bezpośredniego spotkania. Podczas jednego z legnickich wieczorów Miłobędzka stwierdziła: „Tu nareszcie udało mi się nazwać siebie i umieścić $\mathrm{w}$ świecie - w świecie fizycznym i w świecie języka. Być tym, co najmniejsze w całości, ale być wewnątrz tej całości" ${ }^{8}$. Co prawda poetka odwołuje się tutaj do konkretnego wiersza, od kiedy jestem, ale niewykluczone, że w słowach tych pojawiło się odniesienie do konkretnej sytuacji, w jakiej znaleźli się mówiący i słuchający - sytuacji spotkania, sytuacji „nazywania” głosem, sytuacji uobecnienia wierszy w mówieniu.

Nie jestem oczywiście na tyle naiwny, aby wierzyć, że możliwe jest pseudomistyczne osiągnięcie stanu pełnej obecności. „Tu” nigdy nie jest do końca tutejsze, a „teraz” nigdy w pełni teraźniejsze. Zawsze są poślizgi, odbicia, refleksy i refrakcje; zawsze są różnice między czasem mówiącego i czasem słuchacza; zawsze jest zakrzywienie przestrzeni; zawsze są efekty związane $\mathrm{z}$ nieuchronnie retorycznym charakterem języka. Pozostaje jednak faktem to, że głos, który nie jest spłaszczony do postaci druku, zawiera w sobie silny potencjał wydarzenia jednorazowego i niepowtarzalnego, naddatek, który nie wyczerpuje się w wierszach, lecz trwa zawieszony ${ }^{\mathrm{I}}$.

Dobrze, powie ktoś, ale gdzie tu wspólnota? Zastanówmy się. Nie chodzi mi oczywiście o banalne stwierdzenie, że publiczność zgromadzona na sali jest już z zasady wspólnotą (choć zobaczymy jeszcze, że stwierdzenie to wcale nie musi być banalne). Obecność w tej samej przestrzeni i w tym samym czasie niczego nie gwarantuje. Taką gwarancją nie jest również fakt, że w grę wchodzi spotkanie z poetą/poetką. Jeszcze inaczej: to, co wspólne, wcale nie musi dawać efektu wspólnoty.

I8 K. Miłobędzka, znikam jestem..., s. 21.

I9 Na czym polegałby spłaszczający efekt druku i pisma? I czy nie moglibyśmy mówić o spłaszczającym efekcie mowy i wszelkiej komunikacji dokonującej się w języku? Możliwości różnicowania mowy w druku są ograniczone. Choć do dyspozycji mamy mnóstwo krojów czcionek, kursywę, podkreślenia, rozstrzelenia i pogrubienia, grę cudzysłowów i innych znaków interpunkcyjnych, tudzież retorykę, która potrafi do pewnego stopnia naśladować rytmy mowy jednak słowo drukowane nie może oddać momentów zawahania, drżenia, nagłej zmiany intonacji, nagłego zaśpiewu, a to właśnie w tych jakościach często zawiera się niepowtarzalność poezji. Z drugiej strony mamy stratygrafię głosu, efekt oddalenia od źródła - efekt, który w jednym z poprzednich przypisów skojarzyłem $\mathrm{z}$ aktorską interpretacją tekstu poetyckiego i który pojawia się też wtedy, gdy swe wiersze czytają autorzy. 
W najprostszym sensie efekt ten pojawia się na skrzyżowaniu różnych częstotliwości głosu i w przestrzeni otworzonej ich bliskością lub bezpośrednim następstwem. Mówienie i słuchanie są tu jakby częścią jednego gestu, jednej sceny - zachodzą na siebie tak ściśle, że nawet nieuchronne odkształcenia autorskich wypowiedzi i odbioru publiczności wzmacniają wrażenie bliskości. Opis takiej sytuacji znajdziemy w jednym $\mathrm{z}$ esejów Waltera J. Onga:

Opozycję słuchanie - czytanie (przebieganie oczyma po sygnałach kodujących dźwięk) uchwycimy lepiej, jeśli wyobrazimy sobie mówcę, który zwraca się do audytorium wyposażonego w teksty. W jakimś momencie mówiący prosi członków audytorium, by wszyscy przeczytali po cichu fragment tekstu. Audytorium natychmiast się rozpada. Przestaje być jednością. Każda jednostka wycofuje się w swój własny mikrokosmos. Kiedy czytelnicy podnoszą wzrok, mówiący musi ponownie zebrać ich w zbiorowość. Jest tak nawet wówczas, gdy to on jest autorem tekstu, który czytali ${ }^{20}$.

Ale „zbiorowość” to niekoniecznie „wspólnota”. To ostatnie stanowi więcej niż sumę jednostek. To pewien projekt, pewna wizja, a jednocześnie nieufność wobec wszystkiego, co zbyt łatwo daje się projektować i uobecniać. Poczucie wspólnoty nie powinno się zamykać $\mathrm{w}$ zaokrąglonej formule; nie powinno wyczerpywać własnego sensu w słowie, które przyjmujemy na wiarę i za dobrą monetę. Pytanie o wspólnotę nie jest - wbrew początkowym oczekiwaniom - ani łatwe, ani oczywiste. Wręcz przeciwnie - od razu natyka się na różnego rodzaju aporie, które nie pozwalają wyjść poza banały i schematy.

9.

Bardzo istotne są w tym kontekście słowa, które Miłobędzka wypowiedziała w kwietniu 2010 r. podczas jednego z wrocławskich spotkań. Wiele $\mathrm{z}$ tych myśli obraca się wokół paradoksu wspólnoty: „trudne odkrycie, że to, co uważało się za złączone, nagle okazuje się rozdzielone. Dramatyczne odkrycie drugiego Ty i swojego stosunku do drugiego człowieka. Próbowanie, ciągłe próbowanie. Od najbliższego kręgu - domu, rodziny, przy-

${ }^{20}$ W.J. Ong, Autor zawesze fikcjonalizuje odbiorce, w: Osoba - świadomość - komunikacja. Antologia, wybór, wstęp, przeł., oprac. J. Japola, Warszawa 2009, s. 60. 
jaciół, więc od najmniejszego" ${ }^{21}$. Moment łączności okazuje się momentem oddzielenia. Wspólnota wyważa samą siebie, i to właśnie dlatego, że jest wspólnotą. Pojawia się „drugie Ty” -lecz ile tu odbić i zwielokrotnień, jak szybko rozmnażają się, a zarazem dzielą, wszystkie „ja” i „ty”. Na końcu zjawia się „ogromne my" ${ }^{22}$. Sformułowanie to interpretuję - chyba wbrew Miłobędzkiej, która nawiązuje w tym momencie do doświadczenia Solidarności - jako sformułowanie odwołujące się raczej do horyzontu zdarzeń niż do nich samych, i raczej jako artykulację przyszłości niż opis przeszłych zdarzeń.

Tak czy inaczej, stosunek Miłobędzkiej do pojęcia wspólnoty nie jest wcale taki prosty, jak moglibyśmy sądzić po pierwszym przeczytaniu jej wypowiedzi. Na każdym piętrze wyczuwalne jest wahanie, wprawiające $\mathrm{w}$ ruch całą machinerię paradoksów i aporii. Tu nie wystarczą proste parafrazy. Za dużo jest intonacyjnych niuansów, zbyt wiele nieokreślonych akcentów i jakby nie do końca poskładanych fraz, abyśmy mogli odfajkować temat „statusu wspólnoty w poezji Krystyny Miłobędzkiej”. Pamiętajmy, że są to kwestie wypowiadane „w obecności” i wywołujące imię wspólnoty w kontekście wspólnoty szerszej i lepiej obecnej. Przy świadomości fantomów i widm wspólnoty. Bez pewności, jak zabrzmi wypowiedziane imię. Czy nie stanie się pseudonimem i szaleństwem czegoś nieobecnego?

Proszę pozwolić, że odwołam się w tym miejscu do znanych analiz Giorgio Agambena. Do przytoczonych poniżej fragmentów Wspólnoty, która nadchodzi nawiązywałem już w kilku tekstach i odwołuję się do nich raz jeszcze - znakomicie bowiem oddają intuicję, która moim zdaniem obecna jest w całej późniejszej twórczości Miłobędzkiej. Warto przy tym pamiętać o mesjanistycznym wymiarze Agambenowskiej myśli, która ciąży ku temu, co niespełnione. W książce znikam jestem wyczuwam to samo wahanie co do istoty tak zasadniczych i wielkich pojęć jak „wspólnota”. Jestem pewien, że Agamben polubiłby wiersze Miłobędzkiej; odnalazłby w nich smak jednostkowości, ciężar głosu, radość czerpaną z przekraczania samego siebie.

Dla Agambena prawdziwa wspólnota, wspólnota przyszłości, „nie jednoczy $w$ istocie, lecz rozmieszcza $w$ istnieniu" ${ }^{23}$, pozwala żyć głębiej i intensywniej, na prawach wiersza, a nie słabej powieści realistycznej. Takiej wspólnoty nie da się przedstawić. Jest

${ }^{21}$ K. Miłobędzka, znikam jestem..., s. 59-60.

22 Ibidem, s. 63.

${ }_{23}$ G. Agamben, Wspólnota, która nadchodzi, przeł. S. Królak, Warszawa 2008, s. 25. 
ona niereprezentowalna $\mathrm{w}$ dwóch znaczeniach tego słowa: nie daje się opisać w ramach paktu mimetycznego i wychodzi poza instytucję reprezentacji politycznej (Agambenowskie „wielkie my" nie może być ruchem politycznym czy społecznym, takim jak na przykład Solidarność). „Nie idzie tu jednak - dodaje filozof - o bierność, nieskrępowanie czy rezygnację"24; jednostki nawiązują kontakt ,jedynie w pustej przestrzeni przykładu, niezwiązane żadną wspólną własnością, żadną tożsamością" ${ }^{25}$.

W wizji Agambena powraca motyw „człowieka bez właściwości" (przykładem takiego człowieka jest dla włoskiego filozofa choćby Robert Walter), ale tym razem brak właściwości okazuje się szansą. Jak wiadomo, aspekt ten charakteryzuje poezję Miłobędzkiej, która w jednym ze swoich najsłynniejszych wierszy wzywa samą siebie do odrzucenia wszelakich określeń osobowych: imienia, ciała, a nawet podmiotowości ${ }^{26}$. Agamben:

gdyby ludzie, na próżno poszukujący własnej tożsamości w zawsze już niewłaściwej, obcej i absurdalnej formie jednostkowości, zdołali pojednać się z ową niewłaściwością jako taką, uczynić z własnego bycia-tak-oto nie jakąś tożsamość i indywidualną własność, ale wyzutą z tożsamości pojedynczość, wspólną i całkowicie wystawioną, innymi słowy, gdyby ludzie mogli nie być-tak-oto, zamknięci w tej czy innej konkretnej tożsamości biograficznej, lecz być jedynie owym tak-oto, swą pojedynczą zewnętrznością i własnym obliczem, to ludzkość po raz pierwszy mogłaby powołać do istnienia wspólnotę bez założeń i bez podmiotów, nawiązać porozumienie, w którym nie byłoby już miejsca na to, czego nie sposób przekazać ${ }^{27}$.

Myślę, że to dość bliskie refleksji, którą poetka stara się wyrazić $\mathrm{w}$ rozmowach $\mathrm{z}$ tomu szare światto - sensem egzystencji i podążającej za nią poezji jest wyjście poza Kartezjański paradygmat istoty ludzkiej definiowanej przez myślenie. To ostatnie jest jednym z momentów charakteryzujących człowieka, momentem ważnym, ale jednak nie najważniejszym. W miejscu myślenia jako samowystarczalnego mechanizmu tworzenia i powielania wszelkiego rodzaju prywatnych i publicznych narracji pojawia się „zżycie się” z sobą i innymi. Przejście to może też być rozumiane jako przejście od pisma do głosu, od poezjopisania do poezji mówionej. Wiersz przestaje być uniwersalnym znakiem,

${ }^{24}$ Ibidem, s. 17.

${ }_{25}$ Ibidem.

${ }^{26}$ Chodzi o wiersz rozpoczynający się od słów: „rozbierz się z Krystyny/ z dziecka matki kobiety”. K. Miłobędzka, zbierane, gubione..., s. 319.

27 G. Agamben, op.cit., s. 71. 
który o każdej porze i w każdym miejscu może być odczytany i zinterpretowany. Staje się za to niepowtarzalnym przypadkiem i unikalnym przykładem; jest czymś, co ma sens tylko raz - potem zostaje już tylko pustą kryptą znaczenia.

10.

Znikam. Jestem. Wyjście poza podmiotowość, poza indywidualną egzystencję ludzką, poza humanizm, a nawet poza świadomość, oznacza również przejście, właściwie zakwestionowanie mocnych granic oddzielających człowieka od innych istot. W pozapoetyckich wypowiedziach Miłobędzkiej implikacja ta nie jest jeszcze oczywista i przybiera postać pytania: „może zdarzy się nam kiedyś solidarność z wszystkim stworzeniem?" ${ }^{28}$. Wiemy jednak, że w wierszach poetka od samego początku zakłada łączność ludzi, zwierząt i roślin. Szczególnie istotne jest tu zakwestionowanie jakościowego rozróżnienia pomiędzy człowiekiem i zwierzęciem. W Agambenowskiej „nadchodzącej wspólnocie” znika wyraźna różnica pomiędzy istotą ludzką $\mathrm{i}$ istotą zwierzęcą. Zwierzę też jest „pojedynczą zewnętrznością” i „, własnym obliczem” - jego udział we wspólnocie jest taki sam jak udział człowieka. I kolejna implikacja: człowiek bez tożsamości i właściwości odróżnia się od zwierząt nie jakościowo, lecz ilościowo. To, co najważniejsze z punktu widzenia „wielkiej wspólnoty” - bycie w bliskości $\mathrm{z}$ innymi, bytowanie jako pozostawanie na mocy przykładu, niezobowiązujące otwarcie na innych członków wspólnoty - jest wspólne ludziom i zwierzętom.

Nie trzeba dodawać, jak blisko tu jesteśmy podstawowych intuicji Miłobędzkiej. Wystarczy pomyśleć o jej Anaglifach, wszystkich tych istotach przewijających się przez kolejne wiersze: meduzach, wronach, jaskółkach. W tomie Pokrewene (1970) powinowactwo zwierząt i ludzi jest jeszcze silniejsze. Wiersz $\mathrm{Na}$ dwu i na czterech łapach:

po co ta przytulność, którą widać przez palce

mało wzięłam a przecież i temu nie wybrzęczę, nie dojrzę, nie dosłucham, ledwo się o mnie otarło i już już własne, kwili dawnym wilkiem, całym matecznikiem obrzęknie

zawsze nie moje, moje co? zawsze to moje, nie moje co? tak zdaje się na człowieka ${ }^{29}$.

${ }^{28}$ K. Miłobędzka, znikam jestem..., s. 63.

${ }^{29}$ K. Miłobędzka, zbierane, gubione..., s. 59. 


\section{I wiersz Dzięciot (z tego samego tomu):}

od czułków dziobów szczypiec za cicha zacicha, siebie $\mathrm{w}$ siebie przelotnie donosi

ja dzięcioł i za przegrodą ja odstuka na głos na głód

na stracenie błyszczy czerwoną pręgą, tam uderzę zasłyszę za słyszę $3^{30}$.

Słowa nie są pewne siebie (,za cicha”? „zacicha”? „zasłyszę” „za słyszę”?). Niepewny siebie pozostaje też człowiek. Ile człowieczego jest w zwierzęciu? Ile zwierzęcego w człowieku? Granice i rozróżnienia znikają - pozostaje „nagie życie” (kolejny Agambenowski termin), kwitnące, pączkujące, rozmnażające się bez końca w wielkim kręgu żywej wspólnoty.

Ponieważ nadal chodzi tu o wspólnotę. I nadal moim obrazem wyjściowym jest obraz poetki czytającej wiersze przed publicznością. Nikt lepiej od Miłobędzkiej nie rozumiał, że wiersz to odruch, gest instynktowny, na poły zwierzęcy ${ }^{31}$. Wszystkie przywołane wcześniej momenty - powstanie wspólnoty bez założeń i przekonań, stwarzanie w tej wspólnocie „ja” i „ty”, gra przykładów i przypadków, wyciągnięcie człowieczeństwa ku zwierzęcości i odwrotnie - łączą się u niej w archetypicznym obrazie, który już wielokrotnie przywoływany, nie może być jednak tutaj pominięty:

Jestem. Współżywa, współczynna, współwinna. Współdzielona, współdrzewna. Współistnieję. [...] Znikam jestem. Współtrwam (z Tobą) w tym szklistym dniu (z tym szklistym dniem w którym znikam) który znika ze mną tak lekko ${ }^{22}$.

Miłobędzka przeczytała tę prozę pod koniec ostatniego z czterech zapisanych w książce Borowca spotkań. Dodała: „Pisany na skrawkach udartego papieru, w wielkim pośpiechu, tak mówił się bez zatrzymania cały tekst" 33 . Ważny jest ten jeden czasownik - wiersz „mówił się”, czyli powstał, wzrastał i skończył się w głosie. Dla czytelników, krytyków, dla potomności, dla hi-

3० Ibidem, s. 85.

$3^{\text {I }}$ Bodaj najlepiej wyraził to Frank O'Hara, pisząc: „To się robi odruchem”. F. O’Hara, Personizm, przeł. P. Sommer, „Literatura na Świecie” 1986, nr 7, s. 43.

${ }^{32}$ K. Miłobędzka, zbierane, gubione..., s. 187.

33 K. Miłobędzka, znikam jestem..., s. 66. 
storyków poezji - dla nich wszystkich pozostał wiersz zupełnie inny. Podobny, ale zupełnie inny. Zapisany, zakonserwowany, przekształcony w skamielinę, spopielony. Krypta chwili. Popiół ułożony w kształty liter. Łatwo go zdmuchnąć, choć właściwie nikt tego nigdy nie robi. Bo i po co?

11.

Zamykam książkę. W powietrzu wirują kartki prześwietlone bladym blaskiem - to okładka tomu. Zamykam książkę, ale wiem, że nie zamykam tamtych czterech spotkań, w trakcie których światło reflektorów mieszało się ze światłem oczu (dla niektórych to mroczki, dla innych zmięte prążki). W odróżnieniu od pisma głos pozostaje naprawdę. Nawet gdyby rozpadły się wszystkie książki, głos wiersza nadal by rozbrzmiewał. W językach ludzi, w powietrzu, w kolejnych przemianach żywiołów. Nie da się go spopielić. Nie da się go nawet zarchiwizować. Pozostaje wiecznie młody, tutaj i teraz; choć przecież za każdym razem brzmi inaczej.

\section{JACEK GUTOROW}

\section{"Together but each of us on our own". Krystyna Miłobędzka and "shared air"}

The paper is an attempt to interpret the work of Krystyna Miłobędzka, one of the most celebrated contemporary Polish poets, in terms suggested by the ideas of the community of readers as well as the institution of the poetry reading understood as a phenomenological/communal event. The analysis is informed by the recently published volume znikam jestem [I disappear I exist], a record of four poetry readings given by Miłobędzka between 2000 and 2010.

\footnotetext{
JACEK GUTOROW - poeta, krytyk literacki, tłumacz. Opublikował sześć tomów poetyckich, ostatnio Nad brzegiem rzeki. 1990-2010 (2010) oraz trzy zbiory krytyczne: Na kresach człowieka. Sześć esejów o dekonstrukcji (2001), Niepodległość głosu. Szkice o poezji polskiej po 1968 roku (2003), Urwany ślad. O wierszach Wirpszy, Karpowicza, Różewicza i Sosnowskiego (2007). Jest autorem monografii Luminous Traversing. Wallace Stevens and the American Sublime (2007) i przekładów poezji amerykańskiej (m.in. Wallace'a Stevensa, Rona Padgetta, Johna Ashbery'ego) i angielskiej (m.in. Simona Armitage'a, Charlesa Tomlinsona, Geoffreya Hilla, Davida Kennedy'ego). Mieszka i pracuje w Opolu.
} 
